\title{
Aging Society and Decline Fertility: How to Respond?
}

\section{Asim Kurjak, Ana Stavljenic Rukavina, Milan Stanojevic}

\begin{abstract}
We are living in the time of aging of almost all societies in the world. There are at least two long-term causes of aging world and a temporary blip that will continue to show up in the figures for the next few decades. The first of the big reasons is that people everywhere are living far longer than they used to. A second and bigger cause of the aging of societies is that people everywhere are having far fewer children, so the younger age groups are much too small to counterbalance the growing number of older people. These facts will certainly turn the world into a different place. In this paper, we would like to stress the relationship between economic growth, aging and decline fertility as well as social consequences of both.
\end{abstract}

Keywords: Aging society, Fertility rate, Gross domestic product.

How to cite this article: Kurjak A, Stavljenic Rukavina A, Stanojevic M. Aging Society and Decline Fertility: How to Respond? Donald School J Ultrasound Obstet Gynecol 2012;6(3):333-341.

\section{Source of support $\mathrm{Nil}$}

Confict of interest: None declared

\section{INTR ODUCTION}

D onald School of U Itrasound in Obstetrics and Gynecology is success story in globalized medicine and we do believe that it is useful to inform from time to time our readers on important problem in global perinatal health. Indeed, we are living in the time of aging of almost all societies in the world.

What is making the world so much older? There are two long-term causes and a temporary blip that will continue to show up in the figures for the next few decades. The first of the big reasons is that people everywhere are living far longer than they used to. A second and bigger, cause of the aging of societies, is that people everywhere are having far fewer children, so the younger age groups are much too small to counterbalance the growing number of older people. These facts will certainly turn the world into a different place. The authors have large experience in the field described elsewhere. ${ }^{1-6}$ In this article, we w ould like to stress the relationship between economic growth, aging and decline fertility as well as social consequences of both.

During the second-half of the 20th century, the global population explosion was the big demographic bogey. Robert M cNamara, president of the World Bank in the 1970s, compared the threat of unmanageable population pressures with the danger of nuclear war. Now that worry has evaporated, and this century is spooking itself with the opposite fear: The onset of demographic decline.
Demographic decline worries people because it is believed to go hand-in-hand with economic decline. But, in the main, demographic decline is the consequence of the low fertility that generally goes with growing prosperity. In J apan, for instance, birth rates fell below the replacement rate of 2.1 children per woman in the mid-1970s and have been particularly low in the past 15 years.

The crucial question is, therefore, to what extent does demographic decline influence economy measured by the growth of gross domestic product (GDP) per person.

\section{SLOW GROWTH AND LOW PRODUCTIVITY}

The problems of aging population is slow growth and low productivity, rising public spending and labor shortages. When the IM F calculated the impact of the recent financial crisis, it was found that the costs will indeed be huge: The fiscal balances of the $\mathrm{G} 20$ advanced countries are likely to deteriorate by $8 \%$ points of GDP in 2008 to 2009. But the IMF also noted that in the longer term these costs will be dwarfed by age-related spending. Looking ahead to the period between now and 2050, it predicted that 'for advanced countries, the fiscal burden of the crisis will be about $10 \%$ of the aging-related costs.' The other $90 \%$ will be extraspending on pensions, heal th and long-term care.

The rich world's population is aging fast, and the poor world is only a few dacades behind (Fig. 1). A ccording to the U nited N ation (UN) latest biennial population forecast, the median age for all countries is due to rise from 29 now to 38 by 2050 . A t present just under $11 \%$ of the world's 6.9

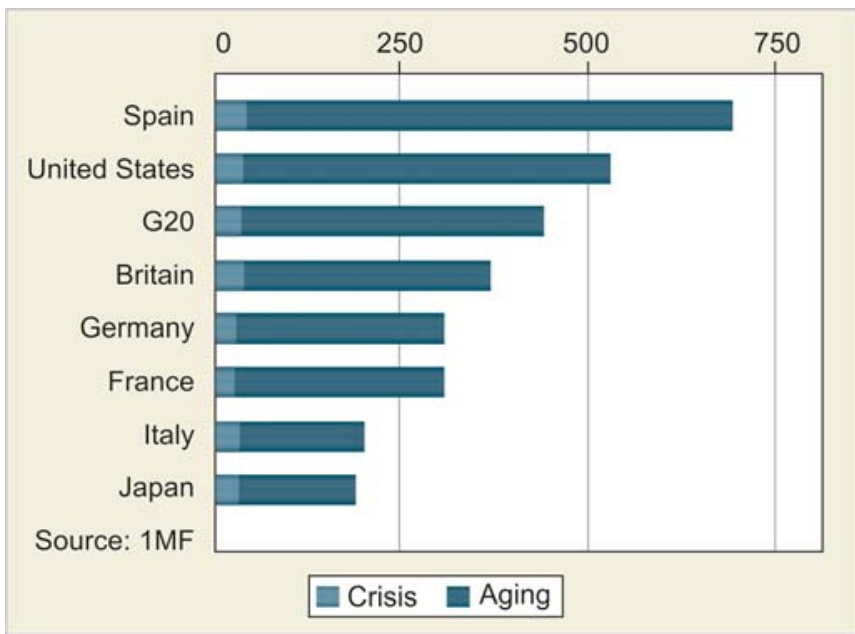

Fig. 1: What crisis? Net present value of impact on fiscal deficit of recent crisis and age-related spending in $2050 \%$ of GDP (Source: IMF) 


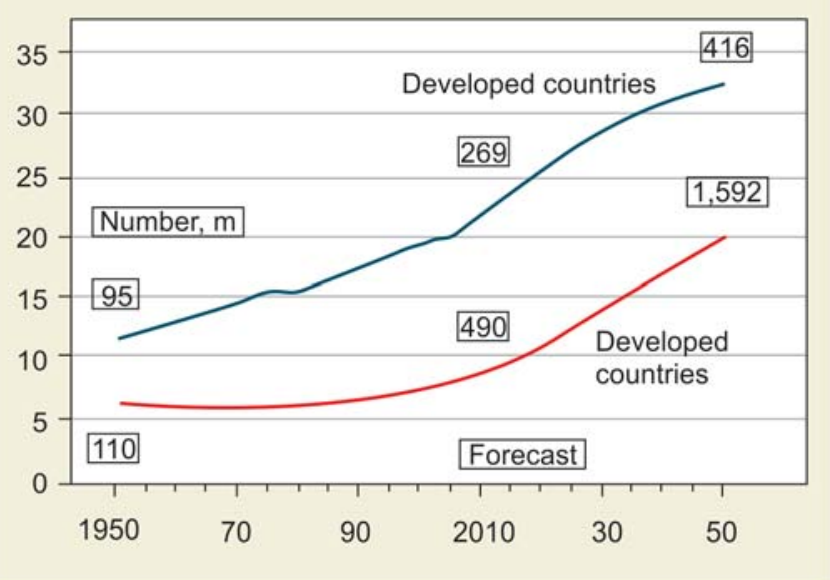

Fig. 2: A graying world: Population aged 60 and over, percentage of total (S ource: World Population Prospectus, United Nations, 2009)

billion people are over 60 . Taking the UN 's central forecast, by 2050 that share will have risen to $22 \%$ (of a population of over 9 billion), and in the developed countries to $33 \%$. To put it another way, in the rich world one person in three will be a pensioner; nearly one in 10 will be over 80 .

$L$ abor forces are now beginning to shrink and numbers of pensioners are starting to rise. By about 2020 aging will be plain for all to see. And there is no escape: B arring huge natural and man-made disasters, demographic changes are much more certain than other long-term predictions (for example, of climate change). Every one of the 2 billion people who will be over 60 in 2050 has already been born (Fig. 2).

The temporary blip that has magnified the effects of lower fertility and greater longevity is the baby-boom that arrived in most rich countries after the second world war. The timing varied slightly from place to place, but in A merica- where the effect was strongest- it covered roughly the 20 years from 1945, a period when nearly 80 million A mericans were born. The first of them are now coming up to retirement. For the next 20 years those babyboomers will be swelling the ranks of pensioners, which will lead to a rapid drop in the working population all over the rich world.

As always, the averages mask considerable diversity. In the richer parts of A sia the populations of J apan, South K orea and T aiwan are al ready old and will rapidly get even older. Europe is split several ways: Germany, Italy, Spain and Croatia, for instance, now have tiny families and are, therefore, aging fast, whereas France, Britain and most of the Nordic countries have more children to keep them younger. In Eastern Europea, and particularly in Russia, birth rates are low and life expectancy has also taken a knock. A merica, has to a resilient birth rate and high immigration, will still be fairly youthful by mid-century.
M ost developing countries do not have to worry about aging yet. Although birth rates have dropped, populations are still young and will remain so for a few decades yet, even though human immunodeficiency virus/acquired immunodeficiency syndrome (HIV/AIDS) has killed off many active adults. But in the longer term the same factors as in the rich world - few er births, longer lives- will cause poorer countries to age too. And even before that happens, the absolute numbers of older people there will swell alarmingly, simply because these countries are so populous.

Alone among developing countries, China is already aging fast. This is mainly because for the past 30 years it has been keeping a tight lid on population growth. This did not quite amount to a 'one-child policy', as it is often called (the average number of children per woman was closer to two), but it was highly effective in stabilizing numbers. The population will peak at about 1.46 billion in 2030 and then decline gently. Although, China has seen stupendous economic growth in recent years, it is still some way off being rich, so it will have trouble absorbing the cost of this rapid aging.

In most rich countries the ratio of people of working age to those of retirement age will deteriorate dramatically over the next few decades. In Japan, for instance, which currently has about three workers to every pensioneral ready one of the low est ratios anywhere- the number will halve by 2050. True, there will be fewer young people to maintain, but children cost less than old people and the overall burden will be much heavier than it is now. The organization for economic cooperation and development (OECD) has estimated that over the next 3 decades the agerelated decline in the labor force could cut growth in its member countries by a third compared with the previous three decades.

For the public finances, an aging population is a huge headache. In countries where public pensions make up the bulk of retirement income, these will either swallow up a mach larger share of the budget or they will have to become a lot less generous, which will meet political resistance (and remember that older people are much more inclined to vote than younger ones). Spending on health, which in most rich countries has been going up relentlessly anyway, is likely to grow even faster as patients get older. A nd because of a huge increase in the number of over-80s, a lot more money, and careful thought, will be needed to provide long-term care for them as they become frailer.

Will the recession make it easier or harder to introduce the required reforms? If people are feeling poorer, they may think that their government should do more for them, not 
less. $Y$ et some say that if everything is in a state of upheaval al ready, change becomes easier to bring about. They cite a phrase currently much used in the Obama White House: 'Never waste a good crisis.'

\section{SUFFER THE LITTLE CHILDREN}

The country's fertility rate (the number of children a woman can expect to have in her life time) is now a rock-bottom 1.3 - the same as in J apan and I taly, where similar attitudes prevail. The chancellor, A ngela M erkel, has acknowledged that her country needs to be more child-friendly.

This is not just because children are nice to have. As almost everybody lives ever longer, a reasonable supply of young people is needed to counterbalance- and fund the pensions of - a growing number of older folk. In fact, fertility rates have dropped steeply in all OECD countries in the past few decades, from an average of 3.2 children per woman in 1960 to 1.6 now. The rate needed to keep the population stable (assuming unchanged mortality rates and no net immigration) is 2.1. A ccording to the UN's latest population estimates, fertility is currently below replacement level in over 70 countries, which account for nearly half the world's population. But even in the remaining, poorer, half of the world, fertility rates have come dow $\mathrm{n}$ spectacularly, from 5.2 in 1970 to 75 to 2.6 now. This has been the most important factor by far in the aging of populations around the world (Figs 3 and 4).

In a few countries where fertility rates are al ready very low, such as Japan and South Korea, they are still falling. But in others the decline has been arrested and in some, including A merica, B ritain and $F$ rance, it has been reversed in the past decade or two. That has encouraged governments in a number of rich countries to believe that, with the right policies, they too could boost fertility to closer to replacement levels and help moderate the social burden of aging. But it will not be easy.

Japan has seen especially rapid graying. Immediately after the second world war it was one of the world's youngest developed countries, with a median age of 22. B ut because so few people were having babies, the median age has doubled since then and is still rising fast. The population, currently about 127 million, has al ready started to decline. It will drop below 100 million by 2046 and continue downward rapidly thereafter.

The only way J apanese women can manage their difficult lives is by postponing marriage and having fewer, if any, children. Because of the country's culture of long-working hours, husbands with good jobs spend little time at home and expect their wives to cope with all domestic tasks. No wonder that $70 \%$ of J apanese women stop work when their first child arrives. If they return to it at all it is usually much

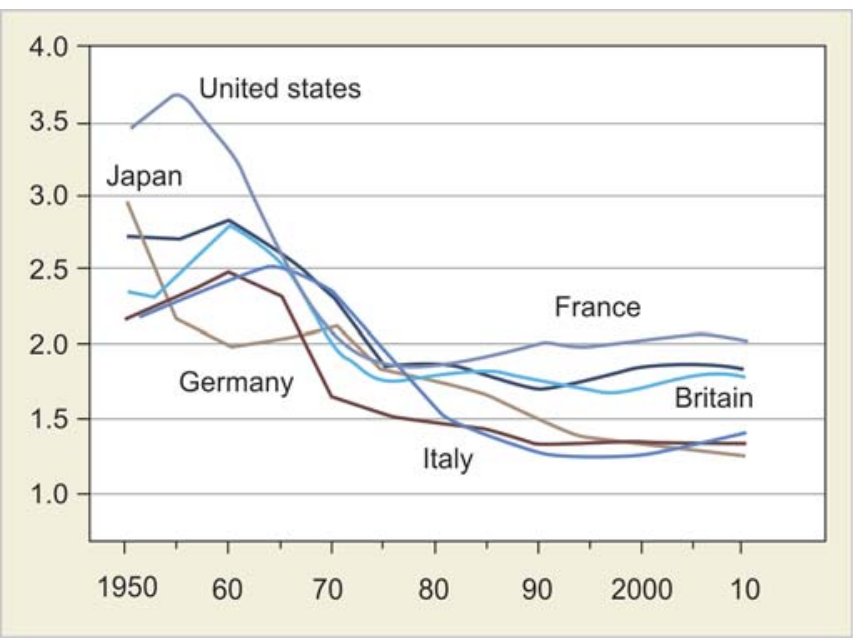

Fig. 3: Hushabye baby: Fertility rates

(Source: World Population Prospectus, United Nations, 2009)

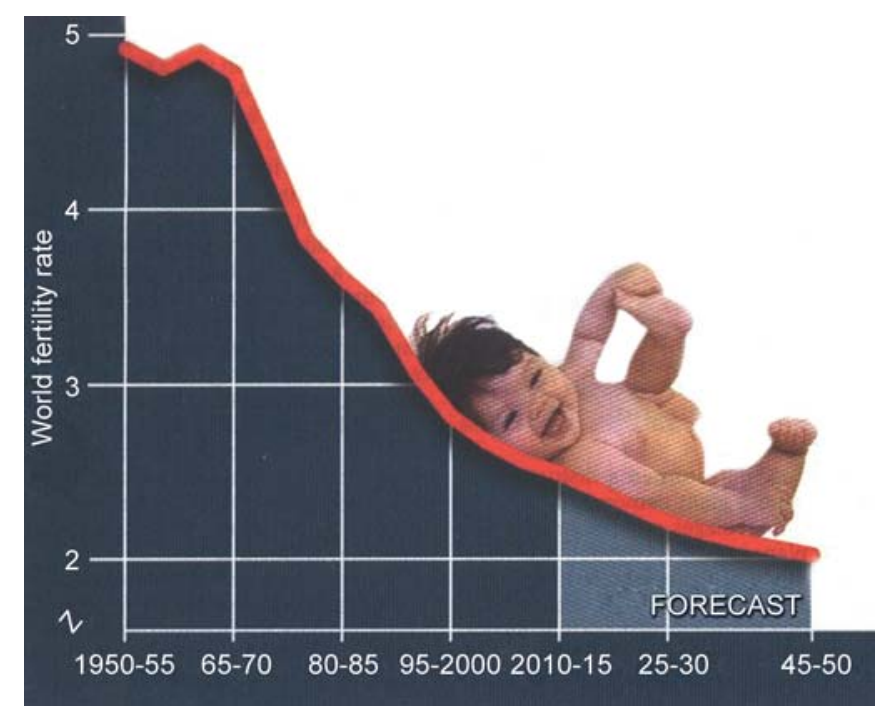

Fig. 4: Go forth and multiply a lot less

later, and then mostly to badly paid and unchallenging parttime jobs. By then they may already be caught up in another domestic bind: L ooking after their husband's old parents.

Japan is an extreme example, but many other rich countries have similar problems. One reason why there are fewer babies is that women everywhere are marrying and having children much later in life. B etween 1970 and 2000 the mean age at which women had their first child in a range of OECD countries rose by more than a year every decade, and many more women now have their families in their 30s. The question is whether they have the same number of children as before but later, or whether they will have fewer overall.

Postponing marriage and childbirth is part of a bigger change in the lives of many women in rich countries. Over the past few decades many more of them have been getting more highly educated and taking paid jobs. That changed their ideas about what they wanted out of life. For a while 
birth rates were lower in countries where lots of women worked outside the home, but more recently that trend has been reversed: Higher fertility and higher employment rates for women go together.

If governments anxious to rejuvenate their populations want her to do that, they can help in a number of ways. Extensive research in 16 OECD countries has shown that there is a strong correlation between high female employment rates and large government cash transfers to families, generous replacement pay during parental leave, the availability of plenty of part-time work and lots of formal child care. Where all these things are present, fertility rates tend to go up. F rance and most of the N ordic countries have embraced such policies and been rewarded with a rise in fertility close to replacement level. It does not come cheap: The OECD reckons that they spend 3 to $4 \%$ of GDP on direct benefits to families, far more than do Germany, J apan and Southern Europe.

The odd ones out are A merica and B ritain, which both have lots of women at work and fertility rates close to replacement level (with immigration making up the rest). Neither of them exactly spoils its families with financial inducements or state-provided child care, but their flexible labor markets make it easy for women to get back into work after childbirth, and public opinion approves of working mothers. They also have high levels of teenage pregnancy that help bump up the figures.

Very low fertility rates now seen in many OECD countries are not inevitable, and governments should try to lessen the obstacles to child bearing faced by individuals and families. B ut having children is a personal choice, and if people really do not want them there is nothing governments can do. The UN expects fertility in developed countries to recover somewhat by 2050 , to 1.8 children per woman, but many experts think that forecast is too optimistic.

\section{WORLD OF METHUSE LAHS}

It is written in the Bible's book of $G$ enesis that M ethusel ah lived to be 969 . He held the record, but there seem to have been plenty of other multicentenarians around at the time, including Noah and old A dam himself. The person with the longest documented life in modern times, J eanne C alment, reached 122 , but no one else has come close.

By the beginning of the 20th century average life expectancy in A merica and the better-off parts of Europe was close to 50 and kept on rising. By mid-century the gains from lower child mortality had mainly run their course. The extra years were coming from higher survival rates among older people. The UN thinks that life expectancy at birth worldwide will go up from 68 years at present to 76 by 2050 and in rich countries from 77 to 83 (These are averages for both sexes; women generally live 5 to 6 years longer than men, for reasons yet to be fathomed). M ost experts now agree that there will be further rises, but disagree about their extent.

Rises in life expectancy have been habitually underestimated because it seemed unlikely that the improvement could go on forever, and just as regularly the figures have had to be revised soon afterward. Some experts now think that there may be no theoretical limit at all, pointing to the huge rise in the number of centenarians in the past few decades. In A merica they are the fastest growing section of the population, with an increase from 3.700 in 1940 to over 100,000 now.

Why are people living ever longer? Robert F ogel at the University of Chicago, a N obel prize winner in economics, reckons that improved medical care and technology are only part of the answer. A nother part, he thinks, is something he has dubbed 'technophysioevolution.' Over the past few centuries humans have developed more resilient physiques because they gained unprecedented control over their environment and their living conditions. W ester people's average body size has increased by $50 \%$ over the past 250 years. Larger body size (but not obesity), M r Fogel's research has shown, is associated with better health and longer life.

But modern life has its downsides too. Stress is often seen as a life-shortening factor - though perhaps the effects are not as lethal as some people think, or else the J apanese, who are famous for working long hours, would not have the highest life expectancy in the world.

A nother hazard of affluence is getting fat. A round 10 to $20 \%$ of the adult population in many rich countries, and over $30 \%$ in A merica, are now clinically obese. Overweight people are at greater risk of cardiovascular and respiratory diseases, cancer, type-II diabetes and other life-shortening ailments- though it is not yet clear whether the effects are strong enough to cancel the trend of greater longevity.

People almost every where could extend their life spans further just by doing a few sensible things, such as not smoking, drinking only in moderation, eating lots of fruit and vegetables and taking regular exercise. Educated folk are better at keeping to such rules, and as a group they live markedly longer than those with only basic schooling. Richer people, unfairly, also live longer than less well-off ones, even in the developed world.

But all this is tinkering at the edges. M ankind's dream has been to conquer aging altogether, and scientists are working on it. Spare-part surgery to replace worn-out bits of the anatomy is al ready well-established and will get better 
with the use of stem cell technology. For a more general effect, experiments on rodents have shown that a severely restricted but balanced diet can increase their life span by about $30 \%$. B ut nobody knows whether this would work in humans, and even if it did, there might be few takers.

By and large, people do now seem to remain in good shape for longer. M oreover, the period of ill health that usually precedes the final goodbye has got shorter in the past few decades, which demographers call 'compression of morbidity' (as a rule of thumb, the bulk of spending an individual's heal th care is concentrated in the last years or two of life, and particularly in the final 6 months). This compression has a variety of causes, including the shift from manual to physically less demanding white-collar work, rising levels of education and much-improved health care and medical technology, from keyhole surgery to heart pacemakers. Eighty, it is said, is the new 65.

Over the past few decades all OECD countries have seen their health spending grow considerably faster than their economies. Aging population will add further momentum to that growth.

$M$ easured by spending on health care as a share of GDP, A merica al ready tops the list, shelling out the equivalent of more than $15 \%$ of GDP. The A merican government's health care spending will be hugely affected by aging because of medicare, the state-funded health care program for the elderly and disabled, and medicaid, the program for the poor (and often also old, because it covers long-term care).

President Barack Obama is determined to reform his country's health care system to improve coverage and, eventually, drive down costs. M ore money does not always produce better results. People in A merica are less healthy and die sooner than in B ritain, which proportionately spends little more than half as much on its health care. A ccording to David Cutler, an economics professor at Harvard who has advised the president on the reform, even doctors believe that around $30 \%$ of money spent on heal th care in A merica is wasted.

The official retirement age in most countries has stayed much the same even though people are living a lot longer, so pensioners have been getting more years in which to enjoy themselves without the pressures of work. In fact, many of them stopped working well before it was time for their gold watch because they were offered irresistible inducements to go early. In A ustria, for instance, the official retirement age for men is 65 but the average actual age is 59 , which means that many of them leave even earlier.

The most obvious thing that needed reconsidering was the retirement age. When A merica introduced its social security (public pension) scheme in 1935 to prevent poverty in old age, the retirement age was 65 and life expectancy at birth was 62. In 1983 a decision was made to raise the official retirement age to 67 , but in steps so tiny that the move will not be completed until 2027. Life expectancy at birth in A merica now averages about 78, so the promise of a pension is worth a great deal more than it was back in the 1930s. As it happens, A merica's public pension system is among the rich world's less generous (which means that financing it should remain manageable), but it still accounts for more than half the average pensioner's income.

Until the early 1990s nobody much thought about whole populations getting older. The UN had the foresight to convene a 'world assembly on aging' back in 1982, but that came and went. By 1994 the World Bank had noticed that something big was happening. In a report entitled 'A verting the Old Age Crisis,' it argued that pension arrangements in most countries were unsustainable.

To tackle the problem of aging population at its root, 'old' countries would have to rejuvenate themselves by having more of their own children. A number of them have tried, some more successfully than others. But it is not a simple matter of offering financial incentives or providing more child care. M odern urban life in rich countries is not well adapted to large families. Women find it hard to combine family and career. They often compromise by having just one child.

And if fertility in aging countries does not pick up? It will not be the end of the world, at least not for quite a while yet, but the world will slowly become a different place. Older societies may be less innovative and more risk-averse than younger ones. By 2025 at the latest, about half the voters in A merica and most of those in W estern European countries will be over 50- and older people turn out to vote in much greater number than younger ones.

There is little that can be done to stop population aging, so the world will have to live with it. But some of the consequences can be ameliorated. $M$ any experts now believe that given the right policies, the effects, though momentous, need not be catastrophic. M ost countries have recognized the need to do something and are beginning to act.

To quote Berkeley, 'We do not really know what population aging will be like, because nobody has done it yet.'

\section{FALLING FERTILITY}

Thomas M althus first published his 'Essay on the Principle of Population,' in which he forecast that population grow th would outstrip the world's food supply, in 1798. His timing was unfortunate, for something started happening around then which made nonsense of his ideas. A s industrialization 
swept through what is now the developed world, fertility fell sharply, first in France, then in B ritain, then throughout Europe and A merica. When people got richer, families got smaller; and as families got smaller, people got richer.

Now, something similar is happening in developing countries. Fertility is falling and families are shrinking in places, such as B razil, Indonesia and even parts of Indiathat people think of as teeming with children. The fertility rate of half the world is now 2.1 or less- the magic number that is consistent with a stable population and is usually called 'the replacement rate of fertility.' Sometime between 2020 and 2050 the world's fertility rate will fall below the global replacement rate.

At a time when $M$ althusian worries are resurgent and people fear the consequences for an overcrowded planet, the decline in fertility is surprising and somew hat reassuring. It means that worries about a population explosion and themselves being exploded-and it carries a lesson about how to solve the problems of climate change.

Today's fall in fertility is both very large and very fast. Poor countries are racing through the same demographic transition as rich ones, starting at an earlier stage of development and moving more quickly. The transition from a rate of five to that of two, which took 130 years to happen in B ritain - from 1800 to 1930- took just 20 years-from 1965 to 1985- in South Korea. Mothers in developing countries today can expect to have three children. Their mothers had six. In some countries the speed of decline in the fertility rate has been astonishing. In Iran, it dropped from seven in 1984 to 1.9 in 2006- and to just 1.5 in Tehran. That is about as fast as social change can happen.

Falling fertility in poor and middle-income societies is a boon in and of itself. It means that, for the first time, the majority of mothers are having the number of children they want, which seems to be- as best one can judge - two (China is an exception: I ts fall in fertility has been coerced).

A nd falling fertility is a boon for what it makes possible, which is economic growth. Demography used to be thought of as neutral for growth. But that was because, until the 1990s, there were few developing countries with records of declining fertility and rising incomes. N ow there are dozens and they show that as countries move from large families and poverty into wealth and aging they pass through a Goldilocks period: A generation or two in which fertility is neither too high nor too low and in which there are few dependent children, few dependent grandparents- and a bulge of adults in the middle who, if conditions are right, make the factories hum. For countries in demographic transition, the fall to replacement fertility is a unique and precious opportunity.
The $M$ althusians are right that the world's population is still increasing and can do a lot more environmental damage before it peaks at just over 9 billion in 2050. That will certainly be the case if poor, fast-growing countries follow the economic trajectories of those in the rich world. The poorest $A$ fricans and $A$ sians produce 0.1 tonnes of $\mathrm{CO}_{2}$ each year, compared with 20 tonnes for each A merican. G rowth is hel ping hundreds of millions to escape grinding poverty. But if the poor copy the pattern of wealth creation that made Europe and A merica rich, they will eat up as many resources as the A mericans do, with grim consequences for the planet. What's more, the parts of the world where populations are growing fastest are also those most vulnerable to climate change, and a rising population will exacerbate the consequences of global warning-water shortages, mass migration and declining food yields.

If population policy can do little more to alleviate environmental damage, then the human race will have to rely on technology and governance to shift the world's economy toward cleaner growth. M ankind needs to devel op more and cheaper technologies that can enable people to enjoy the fruits of economic growth. That is not going to happen unless governments use both carbon pricing and other policies to encourage investment in those technologies and constrain the damage that economic development does to biodiversity. Falling fertility may be making poor people's lives better, but it cannot save the Earth. That lies in our own hands (Fig. 5).

\section{Lower Fertility is Changing the World for the Better}

Sometime in the next few years (if it has not happened al ready) the world will reach a milestone: Half of humanity will be having only enough children to replace itself. That

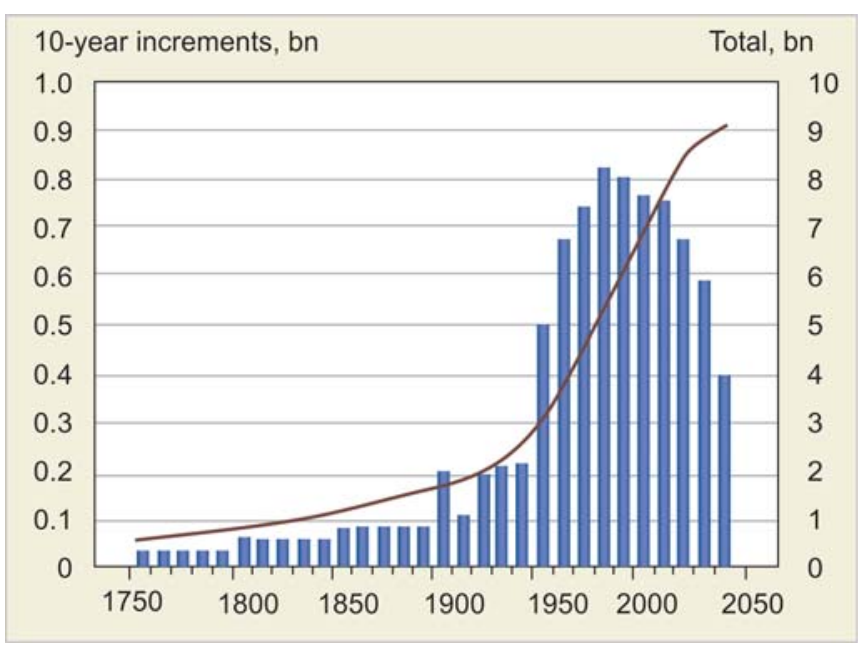

Fig. 5: Rising but falling: World population (Source: UN Population Division) 
is, the fertility rate of half the world will be 2.1 or below. This is the 'replacement level of fertility,' the magic number that causes a country's population to slow down and eventually to stabilize. According to the UN's population division, 2.9 billion people out of a total of 6.5 billion were living in countries at or below this point in 2000 to 2005. The number will rise to 3.4 billion out of 7 billion in the early 2010 s and to over $50 \%$ in the middle of the next decade. The move to replacement level fertility is one of the most dramatic social changes in history.

The fertility rate is a hypothetical, almost conjectural number. It is not the same as the birth rate, which is the number of children born in a year as a share of the total population. Rather, it represents the number of children an average woman is likely to have during her child-bearing years, conventionally taken to be 15 to 49 .

If there were no early deaths, the replacement rate would be 2.0 (actually, fractionally higher because fewer girls are born than boys). T wo parents are replaced by two children.

Since, child mortality is higher in poor countries, the replacement fertility rate is higher there, too. In rich countries it is about 2.1. In poor ones it can go over 3.0. The global average is 2.33. By about 2020, the global fertility rate will dip below the global replacement rate for the first time.

M odern M althusians tend to discount the significance of falling fertility. They believe that there are too many people in the world, so for them, it is the absolute number that matters. And that number is still rising, by a forecast 2.4 billion over the next 40 years. Populations can rise while fertility declines because of inertia, which matters a lot in demography.

A ssuming fertility falls at current rates, says the UN, the world's population will rise from 6.8 to 9.2 billion in 2050, at which point it will stabilize.

B ehind this is a staggering fertility decline. In the 1970s only 24 countries had fertility rates of 2.1 or less, all of them rich. Now there are over 70 such countries, and in every continent, including A frica. B etween 1950 and 2000 the average fertility rate in developing countries fell by half from six to three- three fewer children in each family in just 50 years. Over the same period, Europe went from the peak of the baby boom to the depth of the baby bust and its fertility also fell by almost half, from 2.65 to $1.42-$ but that was a decline of only 1.23 children. The fall in developing countries now is closer to what happened in Europe during 19th- and early 20th century industrialization. But what took place in B ritain over 130 years (1800-1930) took place in South K orea over just 20 (1965-85). Things are moving even faster today. Fertility has dropped further in every South-E ast A sian country (except the Philippines) than it did in Japan. The rate in Bangladesh fell by half from six to three in only 20 years (1980-2000). The same decline took place in M auritius in just 10 (1963-73). M ost sensational of all is the story from Iran.

Why has fertility fallen so fast, so widely? M althus himself thought that richer people would have more children and, as any biologist will tell you, animal populations increase when there is more food around. The link between living standards and fertility exists within countries too. India's poorest state, B ihar, has a fertility rate of 4 ; richer Tamil Nadu and Kerala have rates below 2. Shanghai has had a fertility rate of less than 1.7 since 1975; in Guizhou, China's poorest province, the rate is 2.2 . So strong is the link between wealth and fertility that the few countries where fertility is not falling are those torn apart by war, such as Congo, Liberia and Sierra Leone, where living standards have not risen.

One study in 2002 estimated that as many as a quarter of all pregnancies in developing countries in the 1990s were unintended. $Y$ et another found that more A frican women say they want to use contraceptives but cannot get them (25 million) than actually use them (18 million). Unmet demand in turn implies that fertility in some countries could be even lower than it actually is if more family planning were available. The proportion of women using contraception in Latin A merica and East A sia is four times the A frican rate.

That points to another big reason why fertility is falling: The spread of female education. Go back to the countries where fertility has fallen fastest and you will find remarkable literacy programs. As early as 1962 , for example, $80 \%$ of young women in M auritius could read and write. In Iran in 1976 , only $10 \%$ of rural women aged 20 to 24 were literate. Now that share is $91 \%$, and Iran not only has one of the best-educated populations in the M iddle East but the one in which men and women have the most equal educational chances. Iranian girls aged 15 to 19 have roughly the same number of years of schooling as boys do. Educated women are more likely to go out to work, more likely to demand contraception and less likely to want large families.

Lastly, a special case: China's one-child policy, which began nationwide in the early 1970s. China's population is probably 300 million to 400 million lower now than it would have been without it.

But in its own terms, it has worked-20 million people enter the workforce each year, instead of 40 million and, to the extent that China is polluting less than it would have done, it has benefited the rest of the w orld. Higher standards of living, then, reduce fertility. A nd lower fertility improves 
living standards. This is what C hina's government says. B ut for the moment, A sians and L atinos are enjoying fertility that is neither too hot, nor too cold.

Not entire. Neo-Malthusians think the world has too many people. But for most countries, the population questions that matter most are either: Do we have enough people to support an aging society? Or: How can we take advantage of having just the right number for economic growth? It is fair to say that these perceptions are not mutually exclusive. The world might indeed have the right numbers to boost growth and still have too many for the environment. The right response to that, though, would be to curb pollution and try to alter the pattern of growth to make it less resource-intensive, rather than to control population directly. The reason is that widening replacement-level fertility means population growth is slowing down anyway. A further reduction of fertility would be possible, if family planning were spread to the parts of the world which do not yet have it (notably A frica). But that would only reduce the growth in the world's numbers from 9.2 billion in 2050 to, say, 8.5 billion. To go further would probably require draconian measures, such as sterilization or one-child policies. The bad news is that the girls who will give birth to the coming, larger generations have already been born. The good news is that they will want far fewer children than their mothers or grandmothers did.

\section{SOME RECENT GOOD NEWS}

Although overpopulation plagues much of the developing world, many developed societies are now suffering from the opposite problem: birth rates so low that each generation is smaller than the previous one. M uch of Southern and Eastern Europe, as well as A ustria, Germany, Russia and the developed nations of Southeast A sia, have alarmingly low fertility rates, having, on average, fewer than 1.5 children each, well below the replacement level. At the same time, life expectancies in those places have reached record highs. As a result, the dependency ratio- the ratio of the working population to the nonworking population- has be- come increasingly unfavorable, an it is projected to get more so.

Indeed poulation decline poses a danger to the developed world. History shows that governments can raise birthrates close to replacement levels, if they adopt the right policies. Recently, France and Sweden, for example, have crafted thoughtful, comprehensive and consistent policy, responses that have largely reversed their declining birthrates over the long run.

France was the first country to experience a declining birthrate in the 19th century. French leaders blamed the country's defeat in 1940 on its stagnating demographic, economic and social development. If F rance was to regain its status, is needed a new dynamism - more social justice, a stronger economy and faster population growth. So, France tried to plan itself out of industrial underdevelopment and demographic decay, and it did so through, above all, a generous program of financial support for families with children.

Sweden suffered from extremely low birthrates in the 1930s. When the social democrats came to power at the height of the great depression, one of their economic strategists was Gunnar M yrdal, who in 1934, with his wife A lva, wrote a best-selling book on the population crisis. It argued that if Sweden was to boost its birthrates, women had to be able to both raise children and have careers- a revolutionary idea at the time.

Today, France and Sweden both devote approximately $4 \%$ of their GDPs to supporting families. The Swedish model provides new parents with over 1 year of paid leave based on their salaries, which can be divided between the father and the mother. M ost Swedes send their children to their renowned public preschool system.

Women have the right to return to their jobs after maternity leave on a full-time or part-time basis. The F rench system, for its part, offers mothers more financial incentives and focuses less on early public child care. Today, both countries enjoy heal thy birthrates near replacement level in France, and slightly below replacement level in Sweden.

B ut demographics are not self-regulating, and successful population policies require governments to make long-term investments in encouraging childbirth. This means a great deal of financial support, even in times of austerity; when it comes to population policies, there is no such thing as shortterm success.

Governments trying to institute pronatalist policies will face an uphill battle. The right kind of programs, such as those in France and Sweden, are expensive, and they may clash with vested interests and anger supporters of the traditional family - which is why many developed societies have done nothing or have employed useless half measures.

Countries that fail to take low birthrates seriously do so at their own birthrates and seriously do so at their own peril. Time matters. If they wait too long and get caught in the low-fertility trap, they could find themselves in an uncharted era of depopulation that will be eerily different from anything before. A nd escaping that scenario will be difficult, if not impossible.

\section{THE RICH ARE DIFFERENT}

What happens in poor countries when they reach replacement fertility? The lesson of rich countries is that 
they stay there for decades. German fertility dipped below replacement in 1970 and is still low. A merica is the only rich country that, having fallen below the replacement rate, has risen back above it. Except in a few extraordinary cases- Hong K ong, M acao, parts of Eastern Germanyfertility has not fallen to the very low rate of 1.0 . In most rich countries, the rate stabilizes at about 1.3 and begins to rally. But, the rally varies. Northern Europe-Britain, Scandinavia, France- is seeing big rises in fertility, though not yet to above replacement levels. Russia and Eastern Europe have seen little increase in fertility and M editerranean countries only modest rises.

Indeed, people love to worry-maybe it is a symptom of aging population - but the gloom surrounding population declines misses the main point. The new demographics that are causing population to age and to shrink are something to celebrate. Humanity was once caught in the trap of high fertility and high mortality. Now it has escaped into the freedom of low fertility and low mortality. Politicians may fear the decline of their nations' economic prowess, but people should celebrate the new demographics as heralding a golden age.

\section{REFERENCES}

1. Kurjak A, Carrera J M. Declining fertility in developed world and high maternal mortality in developing countries- how do we respond? (Editorial). J Perinat M ed 2005;33:95-99.
2. Kurjak A, Di Renzo GC, Stanojevic M. Globalization and perinatal medicine-How do we respond? J M aternal-Fetal Neonat M ed 2010;23(4):286-96.

3. M anila bulletin of UN. W orld population will reach $9.2 B$ in 2050, M arch 15, 2007.

4. Kurjak A, Dudenhausen J. Poverty and perinatal health. Editorial. J Perinat Med 2007;35(4):263-65.

5. Kurjak A, Dudenhausen J, Chervenak FA. Does globalization demand a different kind of perinatal research. Editorial. . Perinat Med 2008;36:273-75.

6. A special report on ageing populations. The Economist, June 2009.

\section{ABOUT THE AUTHORS}

\section{Asim Kurjak}

Professor (Emeritus), Department of Obstetrics and Gynecology and Dean of Faculty of $\mathrm{Health}$ Science, Dubrovnik International University, Dubrovnik, Croatia

\section{Ana Stavljenic Rukavina}

Professor (Emeritus), D ubrovnik International University, Faculty of Health Science, Dubrovnik, Croatia

\section{Milan Stanojevic}

Professor, Dubrovnik International University, Faculty of Health Science, Dubrovnik, Croatia

\section{CORRESPONDING AUTHOR}

A sim Kurjak, Professor (Emeritus), Department of Obstetrics and Gynecology, Dubrovnik International University, SV Dominika 4, 20000 Dubrovnik, Croatia, Phone: +385-20-414111, e-mail: asim.kurjak@zg.t-com.hr 